\title{
Bioavailability and poultry fecal excretion of phosphorus from soybean- based diets supplemented with phytase ${ }^{1}$
}

\author{
Bianca Almeida Brandão Martins ${ }^{2}$, Laura Maria de Oliveira Borgatti ${ }^{2}$, Luiz Waldemar de Oliveira \\ Souza $^{3}$, Simi Luiza Durante Aflalo Robassini ${ }^{2}$, Ricardo de Albuquerque $^{4}$ \\ ${ }^{1}$ Research supported by FAPESP, Brazil. \\ 2 Universidade de São Paulo, Pirassununga, São Paulo, Brazil. \\ ${ }^{3}$ University of Minnesota, Saint Paul, Minnesota, USA. \\ ${ }^{4}$ Departamento de Nutrição e Produção Animal - FMVZ - USP, Caixa Postal 23, Rua Duque de Caxias Norte, 225, Pirassununga, São Paulo, \\ 13630-000, Brazil.
}

\begin{abstract}
Five hundred and four 1-day-old Cobb broiler chickens were randomly allotted to 18 treatments and fed a semi-purified basal diet ( $4 \mathrm{~g} / \mathrm{kg}$ total phosphorus) supplemented with 2 levels of supplemental P ( $0.5 \mathrm{or} 1 \mathrm{~g} / \mathrm{kg})$ during $21 \mathrm{days}$ to evaluate performance and bone mineralization; to assess the relative bioavailability of $\mathrm{P}(\mathrm{RBP})$ in wheat meal (WM) and roasted (RS) or extruded soybean meal (ES), with or without phytase (0 or $750 \mathrm{ftu} / \mathrm{kg}$ diet), using dicalcium phosphate (DC) as standard; and to estimate phosphorus excretion. Weight gain (WG), feed intake (FI), feed to gain ratio (FG), and tibia ash weigh (AW) were assessed. For each source, the RBP was calculated by the slope ratio method, when tibia ash weight was regressed on $\mathrm{P}$ ingested. Ingested and fecal $\mathrm{P}$ was determined to calculate $\mathrm{P}$ intake, and $\mathrm{P}$ excretion and excretion rate. Phytase addition increased overall FI, WG, and FG ratio by $3.3,2.6$ and $0.8 \%$, respectively, but differences were not significant. Overall AW was increased by $10.8 \%$ after the enzyme inclusion in the diets. The relative bioavailability of phosphorus values of tested WM, RS, and ES were increased by $6.32,64.32,76.99 \%$, respectively, in response to supplementation of phytase in diets containing WM, RS, and ES, respectively. Phytase reduced P excretion by $12.7 \%$ and the excretion rate by $15.0 \%$, regardless of the phosphorus source or level.
\end{abstract}

Key Words: available phosphorus, bone ash, broiler, phosphorus excretion, phytate, wheat meal

\section{Introduction}

The main characteristics of the modern poultry production are total confinement and high density, resulting in great reject output containing nitrogen, phosphorus and others. Such contaminants, originated from supplemented diets based on cereal grains and oil seeds, represent both environmental pollution and waste of nutrients added to the ration, raising production costs. About two-thirds of $\mathrm{P}$ in the main ingredients of poultry diets are in the phytic form unavailable for non-ruminants, requiring the addition of an inorganic $\mathrm{P}$ to the diets (Denbow et al., 1995). Phytate has the ability to bind mono and divalent cations forming quelate complexes with minerals like $\mathrm{Ca}, \mathrm{Zn}, \mathrm{Fe}$ and $\mathrm{Mn}$ and proteins, lipids and starch (Cosgrove, 1966; Thompson \& Yoon, 1984). It is also an inhibitor of enzymatic actions of alpha-amylase, proteases and lipases (Deshpande \& Cheryan, 1984; Knuckles, 1988).

Solutions for low availability of nutrients include feed processing, such as extrusion and roasting, in attempt to reduce anti-nutritional factors and increase nutrient digestibility (Marsman et al., 1997; Alonso et al., 1998, 2000).
Recently, research studies have been focused on the evaluation of the efficacy of exogenous enzymes upon nutrient availability. After its discovery by Suzuki et al. (1970), the natural phytase has been detected in cereals like rice, wheat, corn, soybean, triticale and sorghum (Vohra \& Satyanarayana, 2003), but low or no enzymatic activity was found in corn and soybean (Selle, 1997). The commercial phytase industrially produced through recombinant technology increases $\mathrm{P}$ availability in vegetal ingredients for non-ruminants, improving intestinal absorption, bone mineral deposition and performance (Qian et al., 1996). Several reports have shown the efficacy of phytase in improving nutrient digestibility (Tejedor et al., 2001), increasing bone $\mathrm{Ca}$ and $\mathrm{P}$ (Teichmann et al., 1998) and reducing P excretion (Denbow et al., 1998; Vohra \& Satyanarayana, 2003).

Modern poultry production requires the reduction of costs and waste output, and the increment of animal performance. Therefore, the objectives of this study were to evaluate the improvement in growth performance and bone ash content in response to enzyme addition; to assess the relative bioavailability of phosphorus in wheat meal, 
and roasted or extruded soybean with or without phytase addition; and to determine the phosphorus excretion of broilers fed phytase-supplemented and non-supplemented diets.

\section{Material and Methods}

The study was conducted at Universidade de São Paulo, southwest of Brazil, with mean temperature of $26.4{ }^{\circ} \mathrm{C}$ (maximum of $36.5^{\circ} \mathrm{C}$; minimum of $22.0^{\circ} \mathrm{C}$ ). All experimental procedures were in agreement with Ethical Principles in Animal Research adopted by the Bioethics Commission of FMVZ/USP.

Five hundred and four one-day-old male Cobb 500 poultry chicks, vaccinated for Marek disease at birth, were allotted to 18 treatments with four replications ( 7 birds/pen; experimental unit). Initial weight was recorded $(65 \pm 1 \mathrm{~g})$ and birds were randomly housed in 3 batteries with 24 cages each $(2.0 \times 1.70 \times 0.73 \mathrm{~m})$ with electric heating $(60 \mathrm{~W}$ incandescent lamps $)$, one linear feeder $(0.64 \times 0.06 \times 0.06 \mathrm{~m})$ and 2 nipple drinkers. Birds were under a 24-hour light/one hour dark lighting program.

A semi-purified basal diet (BD) based on corn starch and soybean meal was produced to meet the requirements of poultry according to the NRC (1994), except for total $\mathrm{P}$, which was kept at $0.40 \%$. From the basal diet, 8 experimental diets were created through addition of 0.05 or $0.10 \%$ of $\mathrm{P}$ from dicalcium phosphate (DC), roasted or extruded soybean (RS and ES, respectively), or wheat meal (WM). Phosphorus sources were added to the diet in substitution to corn starch. Another 9 diets were produced through addition of phytase produced by Aspergillus oryzae (Ronozyme $^{\circledR}$, MSD Nutritional Products, $750 \mathrm{ftu} / \mathrm{kg}$ diet), thus totaling 18 experimental diets (Table 1).

Chromic oxide $(0.20 \%)$ was added to diets as digestibility marker. Water and the isocaloric diets were provided ad libitum during 21 days. The calcium:phosphorus ratio was maintained constant at $2: 1$ by varying limestone and corn starch levels in the different diets. Soybean oil and DL-methionine inclusion were also variable in the different treatments. Experimental diets were analyzed according to the AOAC (1995). Phytase activity of test-ingredients, phytase premix and experimental diets were evaluated by Roche Vitamins using the Vanadate Manual method (Engelen et al., 1994).

Broiler weight and feed intake were weekly recorded to calculate daily weight gain (WG), daily feed intake (FI),

Table 1 - Composition of experimental diets ( $\mathrm{g} / \mathrm{kg}$ fed basis)

\begin{tabular}{|c|c|c|c|c|c|c|c|c|c|}
\hline \multirow[b]{2}{*}{ Ingredients } & \multicolumn{9}{|c|}{ Treatments (diet numbers) ${ }^{1}$} \\
\hline & $\begin{array}{l}\mathrm{BD}(3,12) \\
4.0 \mathrm{~g} / \mathrm{kg} \mathrm{P}\end{array}$ & $\begin{array}{l}\mathrm{DP}(4,13) \\
4.5 \mathrm{~g} / \mathrm{kg} \mathrm{P}\end{array}$ & $\begin{array}{l}\mathrm{DP}(5,14) \\
5.0 \mathrm{~g} / \mathrm{kg} \mathrm{P}\end{array}$ & $\begin{array}{c}\text { WM }(6,15) \\
4.5 \mathrm{~g} / \mathrm{kg} \mathrm{P}\end{array}$ & $\begin{array}{c}\mathrm{WM}(7,16) \\
5.0 \mathrm{~g} / \mathrm{kg} \mathrm{P}\end{array}$ & $\begin{array}{l}\mathrm{RS}(8,17) \\
4.5 \mathrm{~g} / \mathrm{kg} \mathrm{P}\end{array}$ & $\begin{array}{l}\mathrm{RS}(9,18) \\
5.0 \mathrm{~g} / \mathrm{kg} \mathrm{P}\end{array}$ & $\begin{array}{c}\text { ES }(10,19) \\
4.5 \mathrm{~g} / \mathrm{kg} \mathrm{P}\end{array}$ & $\begin{array}{c}\mathrm{ES}(11,20) \\
5.0 \mathrm{~g} / \mathrm{kg} \mathrm{P}\end{array}$ \\
\hline Corn starch & 501.50 & 495.20 & 488.90 & 432.40 & 364.40 & 404.90 & 309.20 & 309.20 & 309.20 \\
\hline Wheat meal & & & & 44.0 & 87.0 & & & & \\
\hline Roasted soybean & & & & & & 87.0 & 173.0 & & \\
\hline Extruded soybean & & & & & & & & 87.00 & 173.00 \\
\hline Soybean oil & 1.70 & 4.30 & 7.00 & 25.00 & 47.00 & 10.00 & 18.00 & 18.00 & 18.00 \\
\hline Soybean meal & 465.00 & 465.00 & 465.00 & 465.00 & 465.00 & 465.00 & 465.00 & 465.00 & 465.00 \\
\hline Salt & 3.50 & 3.50 & 3.50 & 3.50 & 3.50 & 3.50 & 3.50 & 3.50 & 3.50 \\
\hline Limestone & 14.10 & 14.10 & 14.10 & 16.00 & 19.00 & 16.00 & 18.00 & 16.00 & 18.00 \\
\hline Dicalcium phosphate & 5.40 & 8.20 & 11.00 & 5.40 & 5.40 & 5.40 & 5.40 & 5.40 & 5.40 \\
\hline Choline chloride & 0.80 & 0.80 & 0.80 & 0.80 & 0.80 & 0.80 & 0.80 & 0.80 & 0.80 \\
\hline DL-methionine & 3.00 & 3.00 & 3.00 & 2.90 & 2.80 & 2.60 & 2.10 & 2.10 & 2.10 \\
\hline Mineral premix ${ }^{2}$ & 1.00 & 1.00 & 1.00 & 1.00 & 1.00 & 1.00 & 1.00 & 1.00 & 1.00 \\
\hline Vitamin premix $^{3}$ & 4.00 & 4.00 & 4.00 & 4.00 & 4.00 & 4.00 & 4.00 & 4.00 & 4.00 \\
\hline \multicolumn{10}{|l|}{ Chemical composition } \\
\hline Crude protein, $\%$ & 211.00 & 211.00 & 211.00 & 217.8 & 224.60 & 242.90 & 274.50 & 242.90 & 274.50 \\
\hline Ether extract, \% & 3.70 & 3.70 & 3.70 & 5.00 & 6.30 & 19.40 & 34.90 & 19.40 & 34.90 \\
\hline Crude fiber, $\%$ & 32.60 & 32.60 & 32.60 & 37.40 & 42.10 & 37.30 & 42.10 & 37.30 & 42.10 \\
\hline $\mathrm{Ca}, \%$ & 8.00 & 9.00 & 10.00 & 9.00 & 10.00 & 9.00 & 10.00 & 9.00 & 10.00 \\
\hline Total P, \% & 4.00 & 4.50 & 5.00 & 4.50 & 5.00 & 4.50 & 5.00 & 4.50 & 5.00 \\
\hline Non-phytate $\mathrm{P}, \mathrm{g} / \mathrm{kg}$ & 2.20 & 2.70 & 3.10 & 2.30 & 2.40 & 2.30 & 2.40 & 2.30 & 2.40 \\
\hline $\mathrm{ME}, \mathrm{kcal} / \mathrm{kg}$ & 2900 & 2900 & 2900 & 2900 & 2900 & 2900 & 2900 & 2900 & 2900 \\
\hline Methionine, $\mathrm{g} / \mathrm{kg}$ & 7.70 & 7.70 & 7.70 & 7.70 & 7.70 & 7.70 & 7.70 & 7.70 & 7.70 \\
\hline Lysine, $\mathrm{g} / \mathrm{kg}$ & 12.80 & 12.80 & 12.80 & 13.10 & 13.30 & 14.70 & 16.70 & 14.70 & 16.70 \\
\hline Methionine + cystine, $\mathrm{g} / \mathrm{kg}$ & 10.80 & 10.80 & 10.80 & 11.00 & 11.10 & 11.30 & 11.80 & 11.30 & 11.80 \\
\hline
\end{tabular}

BD - basal diet; DC - dicalcium phosphate; WM - wheat meal; RS - roasted soybean; ES - extruded soybean; ME - metabolizable energy; Met + cys - methionine + cystine.

${ }^{1}$ Phytase supplementation: $0 \mathrm{ftu} / \mathrm{kg}$ (diets number 3 to 11 ) or $750 \mathrm{ftu} / \mathrm{kg}$ (diets number 12 to 20 ).

${ }^{2}$ Mineral premix supplies (per kg of diet): iron - $40 \mathrm{mg}$; copper - $12 \mathrm{mg}$; zinc - $120 \mathrm{mg}$; manganese - $100 \mathrm{mg}$; iodine - $2.5 \mathrm{mg}$; cobalt - $0.75 \mathrm{mg}$.

${ }^{3}$ Vitamin premix supplies (per of diet): vitamin A - $10000 \mathrm{IU}$; vitamin D3 - $2000 \mathrm{IU}$; vitamin E - $10 \mathrm{mg}$; vitamin K3 - 2 mg; thiamine - $1 \mathrm{mg}$; riboflavin - 5 mg; piridoxin - 2 mg;

vitamin B 12 - $15.4 \mathrm{mcg}$; nicotinic acid - $125 \mathrm{mg}$; calcium pantothenate - $10 \mathrm{mg}$; folic acid - $0.25 \mathrm{mg}$; biotin - $0.02 \mathrm{mg}$; selenium - $0.1 \mathrm{mg}$; antioxidant - $30 \mathrm{mg}$. 
and feed to gain ratio (FG). At the end of the experimental period, 3 broilers per cage were slaughtered and legs were removed for bone sampling. Left tibias (3 samples/experimental unit) were immediately cleaned after removing, and frozen $\left(-20^{\circ} \mathrm{C}\right)$. After thawing, tibia samples were dried $\left(105^{\circ} \mathrm{C}\right.$; 48 hours) and subjected to ether extraction for 12 hours and weighted, which was followed by calcination $\left(600{ }^{\circ} \mathrm{C}\right.$; 8 hours) and weighting after cooling. Tibia ash weight (WA) was determined (g). Broiler excretion was collected one day before each bird slaughtering, making a pool of 3 samples per repetition and immediately frozen $\left(-20^{\circ} \mathrm{C}\right)$. After thawing, samples were dried $\left(65^{\circ} \mathrm{C}\right)$, processed to $1 \mathrm{~mm}$ in a mash grinder and weighted for determination of dry matter $\left(105^{\circ} \mathrm{C}\right)$. Phosphorus content was determined using calcinated samples $\left(550{ }^{\circ} \mathrm{C} ; 4\right.$ hours $)$ solubilized in hydrochloric acid. Ammonium molybdate and ascorbic acid were added to $0.2 \mathrm{~mL}$ of the mineral solution and reading was performed at $670 \mathrm{~mm}$ by colorimetric method. Results were given in percentage of $\mathrm{P}$ excretion.

Analysis of variance was performed according to a completely randomized block design by initial weight $(0.065 \pm 0.0015 \mathrm{~kg})$ (Snedecor \& Cochran, 1967) and a $4 \times 2 \times 2+2$ factorial arrangement of treatments (4 P sources, 2 levels of P, 2 levels of phytase + basal diets with 0 or $750 \mathrm{ftu} / \mathrm{kg}$ ) using the GLM procedures of software SAS (Statistical Analysis System). Duncan test was used to perform contrasts for sources means, and analysis of variance for $\mathrm{P}$ and phytase levels. Basal diet results were used only to calculate $\mathrm{P}$ availability. Tibia ash weight at 21 days of experiment was regressed on supplemental P levels (SAS, 1990) to assess $\mathrm{P}$ bioavailability by the slope ratio technique (Combs Jr., 1955 cited by Waldroup et al., 1965; Ammerman et al., 1995).

\section{Results and Discussion}

Diets not supplemented with phytase showed some light enzymatic activity (Table 2) probably due to the natural enzyme contained in vegetal ingredients, especially the wheat meal diets (diets number 6 and 7), which presented higher endogenous phytase activity.

This fact can be confirmed by the same pattern of enzymatic activity observed after inclusion of $750 \mathrm{ftu} / \mathrm{kg}$ (diets 11 to 20). When analyses were individually performed on test-ingredients, wheat meal showed phytase activity 36 times higher than roasted soybean meal, and 22 times higher than extruded soybean meal (1044, 29 and $48 \mathrm{ftu} / \mathrm{kg}$, respectively). Those findings are in agreement with literature reports (Selle, 1997; Vohra \& Satyanarayana, 2003).

Additionally, the phytase premix showed about 1.6 times the expected enzyme activity (14330 vs $9000 \mathrm{ftu} / \mathrm{kg}$ ). Phytase was reported by Augspurger et al. (2003) with $2875 \mathrm{ftu} / \mathrm{g}$ of analyzed activity when the level guaranteed by the manufacturer was $2500 \mathrm{ftu} / \mathrm{g}$ premix, confirming that it is not uncommon to find commercial products with activity higher than the displayed in labels.

On the other hand, the standard assay procedures for determination of phytase activity include one step where the release of inorganic $\mathrm{P}$ is measured at $\mathrm{pH} 5.5$ (Figueiredo et al., 2000). However, the optimal pH for the enzyme activity is bimodal (4.0 and 4.5). Therefore, the enzymatic activity observed at bench top assays does not necessarily reflect the in vivo activity.

Broilers fed non-supplemented diets ingested $40.32 \mathrm{~g} /$ day $( \pm 2.84)$ regardless of the P level (Table 3 ), while the overall feed intake for the phytase-supplemented diets was $41.68 \mathrm{~g} /$ day $( \pm 3.83)$.

Table 2 - Phytase activity (ftu/kg) expected and analyzed in the experimental diets, test-ingredients, and phytase premix

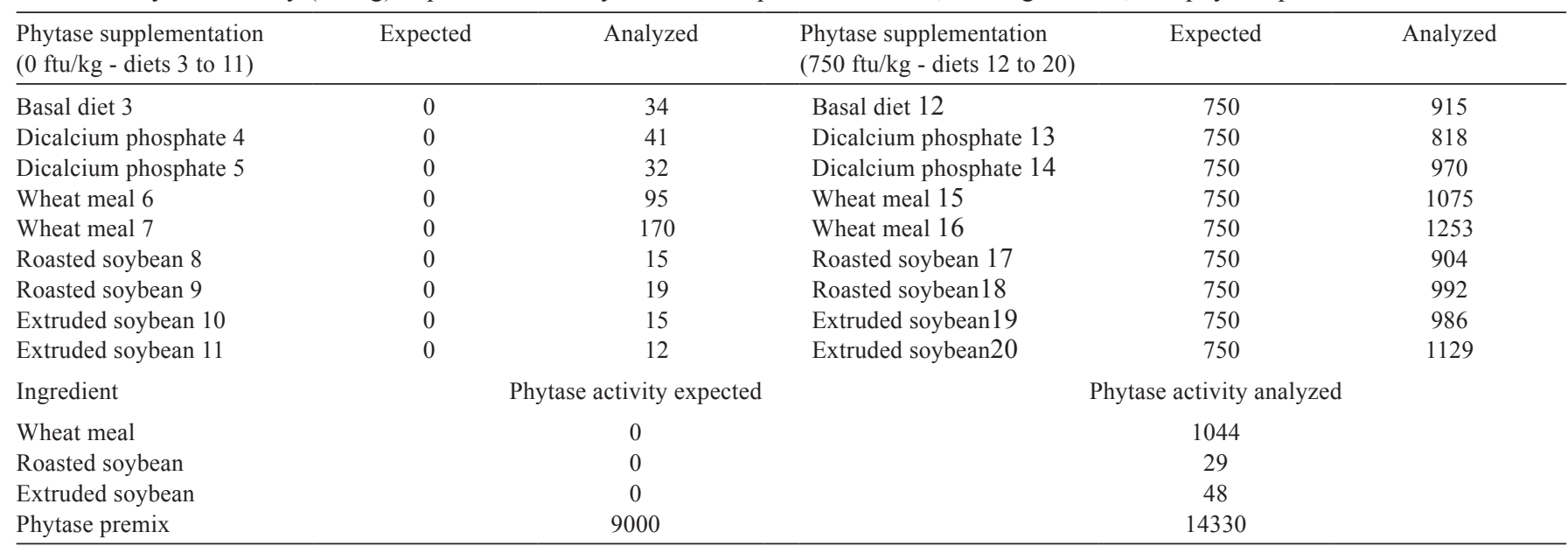


Overall, broilers fed 0 or $750 \mathrm{ftu} / \mathrm{kg}$ of diet ingested similar amount of ration regardless of the $\mathrm{P}$ source or level, indicating that phytase did not influence feed intake ( $\mathrm{P}>0.01)$, as reported in the literature. Costa et al. (2007) and Assuena et al. (2009) reported no differences in the feed intake of broilers fed diets with phytase levels varying from 250 to $1,000 \mathrm{ftu} / \mathrm{kg}$.

Feed intake was reduced by the use of roasted soybean meal for non-supplemented diets $(\mathrm{P}<0.05)$, but such difference was not observed for the phytase-supplemented diet. Considering the $750 \mathrm{ftu} / \mathrm{kg}$ level, there was a lower feed intake $(\mathrm{P}<0.05)$ regardless of the $\mathrm{P}$ source. The overall feed intake was only different $(\mathrm{P}<0.05)$ between the dicalcium phosphate and the roasted soybean meal diets.

Birds fed diets supplemented with 0 or $750 \mathrm{ftu} / \mathrm{kg}$ gained $24.36 \mathrm{~g} /$ day $( \pm 2.02)$ or $25.00 \mathrm{~g} /$ day $( \pm 2.57)$ of body weight, respectively (Table 4).
As observed for feed intake, weight gain was not affected by supplementation of the enzyme in experimental diets, regardless of $\mathrm{P}$ source or level. However, Tejedor et al. (2001) verified that both 500 and $750 \mathrm{ftu} / \mathrm{kg}$ can improve weight gain of broilers by $3.4 \%$ and $2.8 \%$, respectively. On the other hand, Costa et al. (2007) observed that different enzymes, at the same level $(500 \mathrm{ftu} / \mathrm{kg})$, can result in differences in weight gain, when compared with nonsupplemented diets. Assuena et al. (2009) reported a linear reduction in weight gain of 21 and 42 day-old broilers as a result of supplementation with levels higher than $500 \mathrm{ftu} / \mathrm{kg}$, with marked impairment of this variable at $1,000 \mathrm{ftu} / \mathrm{kg}$.

In this study, weight gain was only affected $(\mathrm{P}<0.05)$ by the P level at both phytase levels.

Feed to gain ratio was $1.659 \mathrm{~g} / \mathrm{kg}( \pm 92)$ and $1.672 \mathrm{~g} / \mathrm{kg}$ $( \pm 110)$ for broilers fed diets containing 0 or $750 \mathrm{ftu} / \mathrm{kg}$, respectively (Table 5).

Table 3 - Feed intake (g/day) of 22-day-old broilers fed diets with different supplemental P sources containing 0 or 750 phytase units ${ }^{1}$

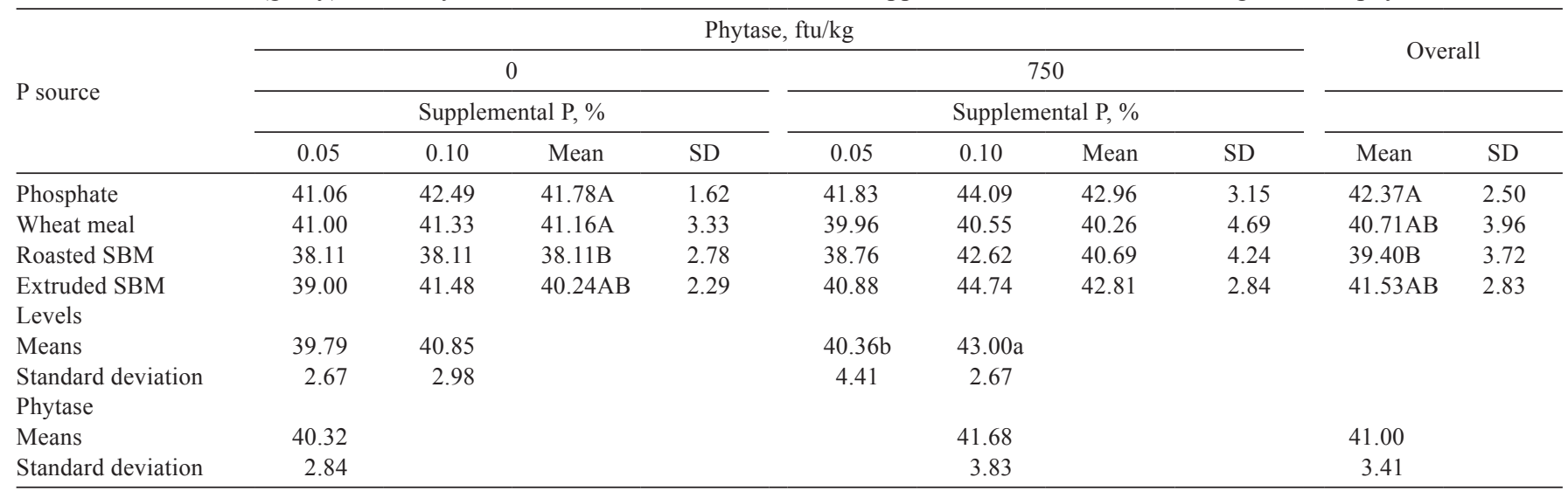

Means with different capital letters in the same column are different $(\mathrm{P}<0.05)$ by the Duncan test.

Means followed by different lowercase letters in the same row are different $(\mathrm{P}<0.05)$ by analysis of variance.

SBM - soybean meal; SD - standard deviation.

${ }^{1}$ Birds fed basal diet $(\mathrm{P}=0.40 \%$ ), with 0 or $750 \mathrm{ftu} / \mathrm{kg}$ of diet showed average feed intake of $36.92 \mathrm{or} 39.11 \mathrm{~g} /$ day, respectively.

Table 4 - Weight gain (g/day) of 22-day-old broilers fed diets with different supplemental P sources containing 0 or 750 phytase units ${ }^{1}$

\begin{tabular}{|c|c|c|c|c|c|c|c|c|c|c|}
\hline \multirow{4}{*}{$\mathrm{P}$ source } & \multicolumn{8}{|c|}{ Phytase, $\mathrm{ftu} / \mathrm{kg}$} & \multirow{2}{*}{\multicolumn{2}{|c|}{ Overall }} \\
\hline & \multicolumn{4}{|c|}{0} & \multicolumn{4}{|c|}{750} & & \\
\hline & \multicolumn{4}{|c|}{ Supplemental P, \% } & \multicolumn{4}{|c|}{ Supplemental P, \% } & & \\
\hline & 0.05 & 0.10 & Mean & $\mathrm{SD}$ & 0.05 & 0.10 & Mean & $\mathrm{SD}$ & Mean & SD \\
\hline Phosphate & 23.29 & 24.88 & 24.08 & 1.09 & 24.16 & 25.57 & 24.87 & 1.70 & 24.47 & 1.44 \\
\hline Wheat meal & 23.98 & 26.16 & 25.07 & 2.71 & 23.09 & 25.04 & 24.07 & 2.20 & 24.57 & 2.44 \\
\hline Roasted SBM & 23.45 & 23.40 & 23.42 & 1.79 & 23.57 & 26.74 & 25.16 & 3.52 & 24.29 & 2.84 \\
\hline $\begin{array}{l}\text { Extruded SBM } \\
\text { Levels }\end{array}$ & 23.28 & 26.47 & 24.87 & 2.08 & 24.40 & 27.41 & 25.91 & 2.68 & 25.39 & 2.38 \\
\hline Means & $23.50 \mathrm{~b}$ & $25.23 \mathrm{a}$ & & & $23.81 \mathrm{~b}$ & $26.19 a$ & & & & \\
\hline $\begin{array}{l}\text { Standard deviation } \\
\text { Phytase }\end{array}$ & 1.76 & 1.94 & & & 2.6 & 1.97 & & & & \\
\hline Means & & 24.36 & & & & 25.00 & & & 24.68 & \\
\hline Standard deviation & & 2.02 & & & & 2.57 & & & 2.32 & \\
\hline
\end{tabular}

Means followed by different capital letters in the same column are different $(\mathrm{P}<0.05)$ by the Duncan test.

Means followed by different lowercase letters in the same row are different $(\mathrm{P}<0.05)$ by analysis of variance.

SBM - soybean meal; SD - standard deviation.

${ }^{1}$ Birds fed basal diet $(\mathrm{P}=0.40 \%$ ), with 0 or $750 \mathrm{ftu} / \mathrm{kg}$ of diet showed average weight gain of 20.42 or $20.01 \mathrm{~g} /$ day, respectively 
Broilers fed non-supplemented or supplemented diets did not differ $(\mathrm{P}<0.05)$ in feed to gain ratio, confirming the assumption that overall performance was not influenced by dietary level of phytase. Significant difference $(\mathrm{P}<0.05)$ in feed to gain ratio was only observed between nonsupplemented diets containing different $P$ levels.

Data on feed to gain ratio is available, but still not consistent. Phytase improved feed to gain ratio by $3 \%$ at 500 and $750 \mathrm{ftu} / \mathrm{kg}$ (Tejedor et al., 2001) in broilers from 10 to 24 days of age, and $1.3 \%$ at $500 \mathrm{ftu} / \mathrm{kg}$ (Costa et al., 2007) in 21-day-old broilers.

However, Assuena et al. (2009) showed that diets containing 750 or $1,000 \mathrm{ftu} / \mathrm{kg}$ of diet resulted in increase of feed to gain ratio in broilers from 1 to 21 or 22-42 days of age. Those authors concluded that those phytase levels impaired performance, but at $500 \mathrm{ftu} / \mathrm{kg}$, feed to gain ratio was better than the control diet. Alvarenga et al. (2011) verified that diets with lower ME $(2,850 \mathrm{kcal} / \mathrm{kg})$ and crude protein content $(17.0 \%)$ increased feed to gain ratio as a result of phytase supplementation.

The overall ( \pm standard deviation) tibia ash weight was $1.799 \mathrm{mg}$ and $( \pm 222)$ and $2.016 \mathrm{mg}( \pm 247)$ for nonsupplemented and supplemented diets, respectively (Table 6).

It is clear that the $\mathrm{P}$ level affected $(\mathrm{P}<0.05)$ ash weight in presence or absence of the enzyme. Broilers fed diets with $750 \mathrm{ftu} / \mathrm{kg}$ showed higher tibia ash content $(\mathrm{P}<0.05)$ than birds fed non-supplemented diets. On the other hand, differences $(\mathrm{P}<0.05)$ due to $\mathrm{P}$ source were reduced after phytase supplementation, except for the wheat meal diet, which resulted in the lower, different $(\mathrm{P}<0.05)$ tibia ash weight. This observation suggests that phytase supplementation does not increase bone mineralization for diets containing ingredients with natural phytase.
Previous research studies have described the improvement in bone mineralization of broilers in response to phytase supplementation (Powell et al., 2011). Powell et al. (2011) concluded that $500 \mathrm{ftu} / \mathrm{kg}$ results in increased bone breaking strength, bone weight, bone ash weight and percentage of tibia ash.

However, Assuena et al. (2009) observed that 21-dayold broilers fed a control diet (3,050 kcal/kg ME; $21.14 \%$ $\mathrm{CP} ; 0.48 \% \mathrm{aP}$ ) or control diet plus $250 \mathrm{ftu} / \mathrm{kg}$ resulted in higher bone density as compared with diets containing higher levels of phytase. For broilers from 22 to 42 days of age, phytase supplementation reduced bone density up to the level of $785 \mathrm{ftu} / \mathrm{kg}$ and then density started to increase, showing a quadratic effect of phytase.

Oliveira et al. (2008) observed impairment of bone mineralization in broilers fed diets containing $250 \mathrm{ftu} / \mathrm{kg}$ and 100,85 , and $70 \%$ of available $\mathrm{P}$ (aP) requirement. According to the authors, it is possible that the release of bound $\mathrm{Ca}$ from ingredients, besides the organic $\mathrm{P}$, may interfere with $\mathrm{P}$ deposition in the bone matrix. Augspurger et al. (2003) reported that diets containing phytase from Escherichia coli at $500 \mathrm{ftu} / \mathrm{kg}$ resulted in similar tibia ash content of broiler chicks compared with diets supplemented with inorganic P. However, a product from Aspergillus niger resulted in lower bone ash content. Bone breaking strength, fresh and dry bone weight, and bone ash weight of growing-finishing pigs increased linearly in response to increasing phytase levels (Veum et al., 2008).

Obviously, when phytase is added to the DC diet, there is no substrate in the ingredient but the enzyme has effect on the fixed amount of soybean meal present in all diets (Table 1). This soybean meal is not under investigation, but it was verified that the enzyme promoted an average

Table 5 - Feed to gain ratio $(\mathrm{g} / \mathrm{kg})$ of 22 -day-old broilers fed diets with different supplemental P sources containing 0 or 750 phytase units ${ }^{1}$

\begin{tabular}{|c|c|c|c|c|c|c|c|c|c|c|}
\hline \multirow{3}{*}{ P source } & \multicolumn{8}{|c|}{ Phytase, $\mathrm{ftu} / \mathrm{kg}$} & \multirow{2}{*}{\multicolumn{2}{|c|}{ Overall }} \\
\hline & \multicolumn{4}{|c|}{0} & \multicolumn{4}{|c|}{750} & & \\
\hline & \multicolumn{4}{|c|}{ Supplemental P, \% } & \multicolumn{4}{|c|}{ Supplemental P, \% } & & \\
\hline Phosphate & 1.762 & 1.709 & $1.735 \mathrm{~A}$ & 56 & 1.732 & 1.725 & 1.729 & 89 & $1.732 \mathrm{~A}$ & 72 \\
\hline Wheat meal & 1.720 & 1.578 & $1.649 \mathrm{~B}$ & 110 & 1.726 & 1.621 & 1.673 & 138 & $1.662 \mathrm{~B}$ & 121 \\
\hline Roasted SBM & 1.626 & 1.632 & $1.629 \mathrm{~B}$ & 83 & 1.653 & 1.598 & 1.626 & 75 & $1.627 \mathrm{~B}$ & 76 \\
\hline Means & $1.696 \mathrm{a}$ & $1.621 \mathrm{~b}$ & & & 1.699 & 1.646 & & & & \\
\hline Standard deviation & 95 & 73 & & & 120 & 96 & & & & \\
\hline \multicolumn{11}{|l|}{ Phytase } \\
\hline Means & & 1.659 & & & & 1.672 & & & 1.666 & \\
\hline Standard deviation & & 92 & & & & 110 & & & 101 & \\
\hline
\end{tabular}


increase of $14 \%$ in RBP as result of hydrolysis of the phytate content in the soybean (Table 7).

After supplementation of phytase to wheat meal diets, RBP was poorly increased from $74.4 \%$ to $79.4 \%$. Since wheat meal contains $0.85 \%$ total $\mathrm{P}$, the aP content is calculated as $0.63 \%$, which can be increased to $0.67 \%$ after phytase addition. Based on findings from this research and previous reports (Fireman \& Fireman, 1998; Vohra \& Satyanarayana, 2003; van Krimpen \& Esmaeilipour, 2012), it is assumed that the endogenous phytase in wheat meal was able to release most of phytic P, leaving no significant substrate for enzymatic action of microbial phytase added to experimental diets.

The RBP in roasted soybean meal and extruded soybean meal increased by $64.3 \%$ and $77.0 \%$, respectively, as a result of inclusion of phytase in non-supplemented diets. In both diets, the enzyme effect was more evident because of the lack of natural enzyme in the soybean. Furthermore, the improvement seen in the aP from the dicalcium phosphate diet compared with those verified in the roasted soybean meal and extruded soybean meal diets lead us to the conclusion that the extraction process performed in the soybean meal may extinguish some of the anti-nutritional factors like trypsin inhibitors and phytic acid, which affect protein digestibility and $\mathrm{P}$ availability, respectively (Cromwell, 2012).

Previous research from the authors of the present study has pointed out that this criterion is the best for determination of phosphorus bioavailability, as confirmed by other studies (Augspurger et al., 2003; Brum et al., 2006, Oliveira et al., 2008). The overall increase in RBP resulting from phytase supplementation was $22 \%$, regardless of the P source. Surek et al. (2008) also observed that the bioavailability of P was calculated as $78.1 \mathrm{~g} / 100 \mathrm{~g}$ and $79.0 \mathrm{~g} / 100 \mathrm{~g}$ for non-supplemented and supplemented $(500 \mathrm{ftu} / \mathrm{kg})$ diets, respectively, for 21-day-old broilers. Interestingly, this effect was significant in diets with $430 \mu \mathrm{m}$ granulometry (increase of $3.1 \%$ of RBP), but not in diets with $680 \mu \mathrm{m}$, but the authors concluded that phytase improved the efficiency of dietary nutrient utilization. Teichmann et al. (1998) reported that increasing levels of dietary phytase $(300,600$, and $900 \mathrm{ftu} / \mathrm{kg}$ ) linearly increased tibia ash content of broilers, improving $\mathrm{P}$ availability from corn-soybean meal diets containing rice bran. Figueiredo et al. (2000) observed 69.2\% increase in the availability of $\mathrm{P}$ from rice bran for pigs fed diets supplemented with phytase. Aboosadi et al. (1995) and Denbow et al. (1995) also reported improvements in P

Table 6 - Tibia ash weight $(\mathrm{mg})$ of 22-day-old broilers fed diets with different supplemental P sources containing 0 or 750 phytase units ${ }^{1}$

\begin{tabular}{|c|c|c|c|c|c|c|c|c|c|c|}
\hline \multirow{4}{*}{ P source } & \multicolumn{8}{|c|}{ Phytase, $\mathrm{ftu} / \mathrm{kg}$} & \multirow{2}{*}{\multicolumn{2}{|c|}{ Overall }} \\
\hline & \multicolumn{4}{|c|}{0} & \multicolumn{4}{|c|}{750} & & \\
\hline & \multicolumn{4}{|c|}{ Supplemental P, \% } & \multicolumn{4}{|c|}{ Supplemental P, \% } & & \\
\hline & 0.05 & 0.10 & Mean & $\mathrm{SD}$ & 0.05 & 0.10 & Mean & $\mathrm{SD}$ & Mean & SD \\
\hline Phosphate & 1.781 & 2.152 & $1.967 \mathrm{~A}$ & 213 & 1.931 & 2.324 & $2.128 \mathrm{~A}$ & 259 & $2047 \mathrm{~A}$ & 244 \\
\hline Wheat meal & 1.787 & 1.924 & $1.855 \mathrm{AB}$ & 137 & 1.664 & 1.948 & $1.806 \mathrm{~B}$ & 204 & 1830B & 170 \\
\hline Roasted SBM & 1.457 & 1.777 & $1.617 \mathrm{C}$ & 256 & 1.979 & 2.122 & $2.051 \mathrm{~A}$ & 199 & 1834B & 315 \\
\hline $\begin{array}{l}\text { Extruded SBM } \\
\text { P levels }\end{array}$ & 1.709 & 1.802 & $1.755 \mathrm{BC}$ & 117 & 1.964 & 2.193 & $2.079 \mathrm{~A}$ & 226 & 1917B & 241 \\
\hline Means & $1.683 \mathrm{~b}$ & $1.914 \mathrm{a}$ & & & $1.884 \mathrm{~b}$ & $2.147 \mathrm{a}$ & & & & \\
\hline Standard deviation & 167 & 214 & & & 210 & 213 & & & & \\
\hline Phytase & & & & & & & & & & \\
\hline Means & & $1.799 \mathrm{~b}$ & & & & $2.016 \mathrm{a}$ & & & 1907 & \\
\hline Standard deviation & & 222 & & & & 247 & & & 257 & \\
\hline
\end{tabular}

Means followed by different capital letters in the same column are different $(\mathrm{P}<0.05)$ by the Duncan test. Means followed by different lowercase letters in the same row are different $(\mathrm{P}<0.05)$ by analysis of variance.

SBM - soybean meal; SD - standard deviation.

${ }^{1}$ Birds fed basal diet $(\mathrm{P}=0.40 \%)$, with 0 or $750 \mathrm{ftu} / \mathrm{kg}$ of diet showed average tibia ash weight of $1.347 \mathrm{or} 1.572 \mathrm{~g} / \mathrm{kg}$, respectively.

Table 7 - Coefficient of determination $\left(\mathrm{r}^{2}\right)$ and regression equation $(\mathrm{Y}=\mathrm{a}+\mathrm{bx})$ for $\mathrm{P}$ sources using tibia ash content as criterion for relative bioavailability of P (RBP, \%)

\begin{tabular}{|c|c|c|c|c|c|c|}
\hline \multirow{3}{*}{ P sources } & \multicolumn{6}{|c|}{ Phytase, ftu/kg } \\
\hline & \multicolumn{3}{|c|}{0} & \multicolumn{3}{|c|}{750} \\
\hline & $\mathrm{r}^{2}$ & $\mathrm{Y}=\mathrm{a}+\mathrm{bx}$ & RBP & $\mathrm{r}^{2}$ & $\mathrm{Y}=\mathrm{a}+\mathrm{bx}$ & RBP \\
\hline Dicalcium phosphate & 96.17 & $\mathrm{Y}=1362+18.948$ & 100.0 & 87.25 & $Y=1399+21.604$ & 114.0 \\
\hline Wheat meal & 83.19 & $\mathrm{Y}=1395+14.096$ & 74.4 & 87.73 & $\mathrm{Y}=1349+15.046$ & 79.4 \\
\hline Roasted soybean & 51.72 & $\mathrm{Y}=1322+10.781$ & 56.9 & 71.82 & $Y=1450+17.718$ & 93.5 \\
\hline Extruded soybean & 72.35 & $\mathrm{Y}=1402+10.708$ & 56.5 & 80.75 & $\mathrm{Y}=1423+18.957$ & 100.0 \\
\hline
\end{tabular}


availability and higher bone mineralization as result of phytase supplementation.

Overall ( \pm standard deviation), the $\mathrm{P}$ intake ( $\mathrm{mg} /$ day) was $1.93( \pm 0.32)$ and $1.99( \pm 0.38)$ for 0 and $750 \mathrm{ftu} / \mathrm{kg}$, respectively (Table 8).

Daily P excretion (mg/day) was $0.71( \pm 0.11)$ and 0.63 $( \pm 0.11)$, and $\mathrm{P}$ excretion rate was $0.69( \pm 0.07)$ and 0.60 $( \pm 0.08)$ for diets with and without phytase, respectively. There is a difference in $\mathrm{P}$ intake because of the $\mathrm{P}$ source at $0 \mathrm{ftu} / \mathrm{kg}$ only between dicalcium phosphate and roasted soybean meal $(\mathrm{P}<0.05)$, but not at $750 \mathrm{ftu} / \mathrm{kg}$ (Table 8$)$.

On the other hand, data show that broilers consuming diets with different $P$ sources, regardless of the phytase or $P$ level, did not have different $\mathrm{P}$ ingestion $(\mathrm{P}<0.05)$.

Considering both pieces of information, it was assumed that $\mathrm{P}$ intake ( $\mathrm{mg} /$ day) was not influenced by the different sources of supplemental P. Phosphorus excretion (mg/day) showed similar pattern to intake. At $0 \mathrm{ftu} / \mathrm{kg}$, the source with the highest intake was different from the source with the lowest intake $(\mathrm{P}<0.05)$. However, that was the only difference between the 4 studied sources of supplemental $\mathrm{P}$, and data suggest that the source of supplemental $\mathrm{P}$ did not influence $\mathrm{P}$ intake in $\mathrm{mg} /$ day. The rate of excreted $\mathrm{P}(\%)$ was different at both enzyme levels. At $0 \mathrm{ftu} / \mathrm{kg}$, the highest excretion was for dicalcium phosphate, differing from wheat meal $(\mathrm{P}<0.05)$, and then, differing from the roasted soybean meal and extruded soybean meal, following the same sequence of P availability (Table 6). At $750 \mathrm{ftu} / \mathrm{kg}$, those differences are reduced, but the dicalcium phosphate and wheat meal are still the sources with highest $P$ excretion rate $(\mathrm{P}<0.05)$. Regardless of the $\mathrm{P}$ level or phytase addition, dicalcium phosphate showed the highest $\mathrm{P}$ excretion (\%), differing from wheat meal. Roasted soybean meal and extruded soybean meal resulted in significantly lower excretion compared with the first two sources $(\mathrm{P}<0.05)$. It is clear that at both levels of phytase, $\mathrm{P}$ intake ( $\mathrm{mg}$ /day) was higher $(\mathrm{P}<0.05)$ for broilers fed $0.50 \%$ total $\mathrm{P}$ compared with $0.45 \%$ total $\mathrm{P}$, regardless of the $\mathrm{P}$ source.

The amount of $\mathrm{P}$ excreted ( $\mathrm{mg} /$ day) was also different $(\mathrm{P}<0.05)$ for the different levels of supplemental $\mathrm{P}$, following the same pattern observed for ingested $\mathrm{P}(\mathrm{mg} /$ day). Nonetheless, the difference in excretion rate was observed only when diets did not contain phytase $(\mathrm{P}<0.05)$, suggesting that the enzyme reduced the differences in excretion between the two levels of dietary P. Most of the differences observed at $0 \mathrm{ftu} / \mathrm{kg}$ were not seen at $750 \mathrm{ftu} / \mathrm{kg}$ (Table 8). The P intake was similar for chicks consuming both levels of phytase in the diet.

However, the amount of fecal P (mg/day) was higher $(\mathrm{P}<0.05)$ for diets without the enzyme. Indeed, the rate of excreted $\mathrm{P}$ was higher $(\mathrm{P}<0.05)$ for non-supplemented diets, compared with diets containing the enzyme. It is well documented that dietary P level has a major influence on the total P intake (Yi et al., 1996). Previous reports have indicated that phytase can increase $\mathrm{P}$ ingestion when dietary levels do not meet the poultry requirements (Ahmad et al., 2000), which may not be the case of the present research. Denbow et al. (1998) reported that levels of supplemental P increased this nutrient excretion, but feeding corn-soybean diets with 400,800 , and $1200 \mathrm{ftu} / \mathrm{kg}$ result in decrease of

Table 8 - Phosphorus intake and excretion of 22-day-old broilers fed diets (4 g/kg total P) with supplemental P from inorganic or organic sources, with or without phytase addition

\begin{tabular}{|c|c|c|c|c|c|c|c|c|}
\hline & \multicolumn{4}{|c|}{$0 \mathrm{ftu} / \mathrm{kg}$} & \multicolumn{4}{|c|}{$750 \mathrm{ftu} / \mathrm{kg}$} \\
\hline & \multicolumn{4}{|c|}{ Supplemental P level, g/kg } & \multicolumn{4}{|c|}{ Supplemental P level, g/kg } \\
\hline & 0.05 & 0.10 & Mean & $\mathrm{SD}$ & 0.05 & 0.10 & Mean & $\mathrm{SD}$ \\
\hline \multicolumn{9}{|l|}{ P intake, mg/day ${ }^{1}$} \\
\hline Phosphate & 1.94 & 2.25 & $2.09 \mathrm{a}$ & 0.22 & 1.83 & 2.30 & 2.06 & 0.32 \\
\hline Wheat meal & 1.83 & 2.06 & $1.94 \mathrm{ab}$ & 0.35 & 1.89 & 1.91 & 1.90 & 0.50 \\
\hline Roasted soybean & 1.73 & 1.75 & $1.74 b$ & 0.22 & 1.84 & 2.04 & 1.94 & 0.26 \\
\hline Extruded soybean & 1.70 & 2.22 & $1.96 \mathrm{ab}$ & 0.41 & 1.69 & 2.44 & 2.06 & 0.45 \\
\hline \multicolumn{9}{|c|}{ P excretion, mg/day ${ }^{1}$} \\
\hline Phosphate & 0.66 & 0.75 & $0.71 \mathrm{ab}$ & 0.06 & 0.60 & 0.72 & 0.66 & 0.09 \\
\hline Wheat meal & 0.68 & 0.84 & $0.76 \mathrm{a}$ & 0.11 & 0.52 & 0.68 & 0.60 & 0.15 \\
\hline Roasted soybean & 0.61 & 0.70 & $0.66 \mathrm{~b}$ & 0.12 & 0.57 & 0.65 & 0.61 & 0.11 \\
\hline Extruded soybean & 0.59 & 0.82 & $0.71 \mathrm{ab}$ & 0.14 & 0.60 & 0.68 & 0.64 & 0.07 \\
\hline \multicolumn{9}{|l|}{$\mathrm{P}$ excretion, $\%{ }^{1}$} \\
\hline Phosphate & 0.74 & 0.78 & $0.76 \mathrm{a}$ & 0.03 & 0.65 & 0.72 & $0.69 \mathrm{a}$ & 0.04 \\
\hline Wheat meal & 0.69 & 0.77 & $0.73 b$ & 0.06 & 0.62 & 0.66 & $0.64 \mathrm{a}$ & 0.06 \\
\hline Roasted soybean & 0.64 & 0.65 & $0.64 \mathrm{c}$ & 0.04 & 0.51 & 0.55 & $0.53 b$ & 0.04 \\
\hline Extruded soybean & 0.62 & 0.65 & $0.63 \mathrm{c}$ & 0.03 & 0.55 & 0.52 & $0.54 b$ & 0.04 \\
\hline
\end{tabular}

Means followed by different letters in the same column are significantly different by Duncan test $(\mathrm{P}<0.05)$.

SD - standard deviation.

${ }^{1}$ Birds fed basal diets ( $4.0 \mathrm{~g} / \mathrm{kg}$ total $\left.\mathrm{P}\right)$ with 0 or $750 \mathrm{ftu} / \mathrm{kg}$ showed $\mathrm{P}$ intake of 1.52 and $1.53 \mathrm{mg} / \mathrm{day}, \mathrm{P}$ excretion of 0.50 and $0.46 \mathrm{mg} / \mathrm{day}$, and P excretion of 6.6 and $5.7 \%$, respectively. 
excretion up to $18.0 \%$ for broilers. Applegate et al. (2003) reported $33 \%$ reduction of $\mathrm{P}$ excreted to the environment when aP was reduced in phytase-supplemented diets. The same effect was observed by Laurentiz et al. (2007), who observed up to $55 \%$ reduction in $\mathrm{P}$ excretion when this nutrient was reduced and phytase was added to poultry diets from starter to finishing phases. According to Zyla et al. (2000), diets based on wheat and soybean with $0.17 \%$ of available $P$ also can decrease P excretion (19.6\%) when supplemented with $750 \mathrm{ftu} / \mathrm{kg}$, and improvements in the reduction of $\mathrm{P}$ in poultry feces can be obtained by the combination of phytase and acidic phosphatase (Zyla et al., 2001). Among the procedures used to reduce $\mathrm{P}$ excretion (e.g., lowering dietary $\mathrm{P}$ or increasing $\mathrm{P}$ availability), phytase addition is a desirable procedure which can increase $\mathrm{P}$ availability and reduce up to $50.0 \%$ of total $\mathrm{P}$ in the feces (Cromwell \& Coffey, 1991; Kersey et al., 1998; Vohra \& Satyanarayana, 2003). Furthermore, better results are observed whit use of 300-500 ftu/kg in lower rather than higher total P diets (Boling et al., 2000; Yan et al., 2001).

\section{Conclusions}

The level of $750 \mathrm{ftu} / \mathrm{kg}$ of diet does not affect performance of 22-days-old broilers, but is effective in improving bone mineralization and $\mathrm{P}$ bioavailability in soy ingredients, reducing phosphorus output to the environment.

\section{Acknowledgements}

This paper is dedicated to the life, accomplishments and memories of our respected counselor, teacher, researcher and friend, Professor, Doctor Felix Ribeiro de Lima. Authors are also grateful to graduate and undergraduate students of the Department of Animal Nutrition and Production (FMVZ, Universidade de São Paulo) and to Dr. Virgill W. Hays (University of Kentucky, USA) and his encouragement to the students of FMVZ-USP.

\section{References}

ABOOSADI, M.A.; SCAIFE, J.R.; MURRAY, I. et al. Effect of phytase supplementation of diets containing rice bran on growth performance and bone characteristics in broiler chickens. Journal of Animal Science, v.60, p.557-558, 1995.

AHMAD, T.; RASOOL, S.; SARWAR, M. et al. Effect of microbial phytase produced from fungus Aspergillus niger on bioavailability of phosphorus and calcium in broiler chickens. Animal Feed Science and Technology, v.83, p.103-114, 2000.

ALONSO, R.; ORÚE, E.; MARZO, F. Effects of extrusion and conventional processing methods on protein and antinutritional factor contents in pea seeds. Food Chemistry, v.63, p.505-512, 1998.
ALONSO, R., ORÚE, E.; ZABALZA, M. et al. Effect of extrusion cooking on structure and functional properties of pea and kidney beanproteins. Journal of Food Science and Agriculture, v.80, p.397-403, 2000.

ALVARENGA, R.R.; NAGATA, A.K.; RODRIGUES, P.B. et al. Ciência Animal Brasileira, v.12, p.602-609, 2011.

AMMERMAN, C.B.; BAKER, D.H.; LEWIS, A.J. Bioavailability of nutrients for animal: amino acids, mineral and vitamins. San Diego: Academic Press, 1995. 441p.

APPLEGATE, T.J.; ANGEL, R.; CLASSEN, H.L. Effect of dietary calcium, 25-dihydroxycholecalciferol, or bird strain on small intestinal phytase activity in broiler chickens. Poultry Science, v.82, p.1140-1148, 2003.

ASSOCIATION OF OFFICIAL ANALYTICAL CHEMISTRY AOAC. Official methods of analysis. 16.ed. Arlington: AOAC International, 1995.

ASSUENA, V.; JUNQUEIRA, O.M.; DUARTE, K.F. et al. Effect of dietary phytase supplementation on the performance, bone densitometry, and phosphorus and nitrogen excretion of broilers. Revista Brasileira de Ciência Avícola, v.11, p.25-30, 2009.

AUGSPURGER, N.R.; WEBEL, D.M.; LEI, S.G. et al. Efficacy of an E. coli phytase expressed in yeast for releasing phytate-bound phosphorus in young chicks and pigs. Journal of Animal Science, v.81, p.474-483, 2003.

BOLING, S.D.; WEBEL, D.M.; MAVROMICHALIS, I. et al. The effects of citric acid on phytate-phosphorus utilization in young chicks and pigs. Journal of Animal Science, v.78, p.682-689, 2000.

BRUM, P.A.R.; COLDEBELlA, A.; PIRACÉS, F. et al. Efeito da fitase e dos níveis de energia metabolizável das dietas sobre o desempenho, no balanço de fósforo de frangos de corte e na digestibilidade da energia das rações. Concórdia: EMBRAPA, 2006. p.1-3. (Comunicado Técnico 450). Available at: <www. cnpsa.embrapa.br/sgc/sgc_publicacoes/publicacao_q9h6c9i.pdf.> Accessed on: Oct. 10, 2012.

COSGROVE, D.J. The chemistry and biochemistry of inositol polyphosphates. Reviews in Pure \& Applied Chemistry, v.16, p.209-224, 1966.

COSTA, F.G.P.; BRANDÃO, P.A.; BRANDÃO, J.S. et al. Efeito da enzima fitase nas rações de frangos de corte, durante as fases préinicial e inicial. Ciência Agrotecnológica, v.31, n.3, p.865-870, 2007.

CROMWELL, G.L.; COFFEY, R.D. Phosphorus - a key essential nutrient, yet a possible major pollutant - its central role in animal nutrition. In: Biotechnology in the feed industry. Nicholasville: Alltech Tech Publishers, 1991. p.133-145.

CROMWELL, G.L. Soybean meal - The "Gold Standard". Available at: <http://www.uky.edu/ Ag / AnimalSciences/pubs/soybeanmealthegolfstandard.PDF> Accessed on: Sept. 20, 2012.

DENBOW, D.M.; GRABAU, E.A.; LACY, G.H. et al. Soybeans transformed with a fungal phytase gene improve phosphorus availability for broilers. Poultry Science, v.77, p.878-881, 1998.

DENBOW, D.M.; RAVINDRAN, V.; KONERGAY, E.T. et al. Improving phosphorus availability in soybean meal for broilers by supplemental phytase. Poultry Science, v.74, p.1831-1842, 1995.

DESHPANDE, S.S.; CHERYAN, M. Effects of phytate, divalent cátions and their implications on alpha-amylase activity. Journal of Food Science, v.49, p.516-519, 1984.

ENGELEN, A.T.; VAN DER HEEFT, F.C.; RANDSDORP, P.H.G. et al. Simple and rapid determination of phytase activity. Journal AOAC International, v.77, p.760-764, 1994.

FIGUEIRÊDO, A.V.; FIALHO, E.T.; VITTI, D.M.S.S. et al. Ação da fitase sobre a disponibilidade biológica do fósforo, por intermédio da técnica de diluição isotópica, em dietas com farelo de arroz integral para suínos. Revista Brasileira de Zootecnica, v.29, p.177-182, 2000.

FIREMAN, F.A.T.; FIREMAN, A.K.B.A.T. Enzimas na alimentação de suínos. Ciência Rural, v.28, p.173-178, 1998. 
KERSEY, J.H.; SALEH, E.A.; STILBORN, H.I. Effect of dietary phosphorus level, high available phosphorus corn, and microbial phytase on performance and fecal phosphorus content. Poultry Science, v.77, n.71, p.82, 1998. (Suppl.1).

KNUCKLES, B.L. Effect of phytate and other myoinositol phosphate esters on lipase activity. Journal of Food Science, v.50, p.250-252, 1988.

LAURENTIZ, A.C.; JUNQUEIRA, O.M.; FILARDI, R.S. et al. Efeito da adição da enzima fitase em rações para frangos de corte com redução dos níveis de fósforo nas diferentes fases da criação. Ciência Animal Brasileira, v.8, p.207-216, 2007.

MARSMAN, G.; GRUPPEN, H.; VAN DER POELA, A. et al. The effect of thermal processing and enzyme treatments of soybean meal on growth performance, ileal nutrient digestibilities, and chyme characteristics in broiler chicks. Poultry Science, v.76, p.864-872, 1997.

NATIONAL RESEARCH COUNCIL - NRC. Nutrient requirement of poultry. 9.ed. Washington: National Academy of Sciences, 1994. 156p.

OLIVEIRA, M.A.; MARQUES, R.H.; GRAVENA, R.A. et al. Qualidade óssea de frangos alimentados com dietas com fitase e níveis reduzidos de fósforo disponível. Acta Scientia Animal Science, v.30, p.263-268, 2008.

POWELL, S.; BIDNER, T.D.; SOUTHERN, L.L. Phytase supplementation improved growth performance and bone characteristics in broilers fed varying levels of dietary calcium. Poultry Science, v.90, p.604-608, 2011.

QIAN, H.; VEIT, H.P.; KONERGAY, E.T. et al. Effects of supplemental phytase and phosphorus on histological and other tibial bone characteristics and performances of broilers fed semipurified diets. Poultry Science, v.75, p.618-626, 1996.

SELLE, P.H. The potential of microbial phytase the sustainable production of pigs and poultry. In: SHORT COURSE AND FEED TECHNOLOGY, 7., 1997, Ansung. Proceedings... Ansung: Korean Society of Animal Nutrition and Feedstuffs, 1997. p.124.

SNEDECOR, G.W.; COCHRAN, W.G. Statistical methods. 2.ed. Ames: Iowa State University, 1967. 593p.

SUZUKI, U.; YOSHIMURA, K.; TAKAISHI, M. Ueber ein enzym phytase das anhydro-oxy-methilen diphosphorusäure spaltet. Bulletin of the College of Agriculture, v.7, p.503-512, 1970.

SUREK, D.; MAIORKA, A.; DAHLKE, F. et al. Uso de fitase em dietas de diferentes granulometrias para frangos de corte na fase inicial. Ciência Rural, v.38, p.1725-1729, 2008.
TEICHMANN, H.F.; LÓPEZ, J.; LÓPEZ, S.E. Efeito da fitase na biodisponibilidade do fósforo em dietas com farelo de arroz integral para frangos de corte. Revista Brasileira de Zootecnia, v.27, p.338-344, 1998.

TEJEDOR, A.A.; ALBINO, L.F.T.; ROSTAGNO, H.S. et al. Efeito da adição da enzima fitase sobre o desempenho e a digestibilidade ileal de nutrientes. Revista Brasileira de Zootecnia, v.30, p.802-808, 2001.

THOMPSON, L.U.; YOON, J.H. Starch digestibility as affected by polyphenols and phytic acid. Journal of Food Science, v.49, p.1228-1229, 1984.

VAN KRIMPEN, M.; ESMAEILIPOUR, O. The role of intrinsec phytase in diet formulation. Available at: $<\mathrm{http} / / \mathrm{www}$.livestock research.wur.nl/NR/rdonlyres/720D8E9D-B5D6-49BE-8E69CCA73979A943/166745/Krimpen.pdf.>Accessed on: Sept. 20, 2012.

VEUM, T.L.; ELLERSIECK, M.R. Effect of low doses of Aspergillus niger phytase on growth performance, bone strength, and nutrient absorption and excretion by growing and finishing swine fed corn-soybean meal diets deficient in available phosphorus and calcium. Journal of Animal Science, v.86, p.858-870, 2008.

VOHRA, A.; SATYANARAYANA, T. Phytases: microbial sources, production, purification, and potential biotechnological applications. Critical Reviews in Biotechnology, v.23, p.29-60, 2003.

WALDROUP, P.W.; AMMERMAN, C.B.; HARMAS, R.H. A comparison of phosphorus asssay techniques with chicks. Poultry Science, v.44, p.1086-1089, 1965.

YAN, F.; KERSEY, J.H.; WALDROUP, P.W. Phosphorus requirements of broiler chicks three to six weeks of age as influenced by phytase supplementation. Poultry Science, v.80, p.455-459, 2001.

YI, Z.; KONERGAY, E.T.; RAVINDRAN, V. et al. Improving phytase phosphorus availability in corn and soybean meal for broiler using microbial phytase and calculating of phosphorus equivalency values for phytase. Poultry Science, v.75, p.240-249, 1996.

ZYLA, K.; WIKIERA, A.; KORELESKI, J. et al. Comparision of efficacies of a novel Aspergillus niger mycelium with separate and combined effectiveness of phytase, acid phosphatase, and pectinase in dephosphorylation of wheat-based feeds fed to growing broilers. Poultry Science, v.79, p.1434-1443, 2000.

ZYLA. K.; KORELESKI, J.; SWIATKIEWICZ, S. et al. Influence of supplemental enzymes on the performance and phosphorus excreation of broilers fed wheat-based diets to 6 weeks of age. Animal Feed Science and Technology, v.89, p.113-118, 2001. 